\title{
PENGEMBANGAN PENGELOLAAN BERBASIS MASYARAKAT PADA WISATA UJONG KAREUNG DI GAMPONG SUAK INDRAPURI
}

\section{DEVELOPMENT OF COMMUNITY-BASED MANAGEMENT OF UJONG KAREUNG TOURISTS IN GAMPONG SUAK INDRAPURI}

\author{
Ika Kusumawati \\ ${ }^{1}$ Prodi Sumberdaya Akuatik Fakultas Perikanan dan IImu Kelautan Universitas Teuku Umar \\ Korespodensi: ikakusumawati@utu.ac.id
}

\begin{abstract}
ABSTRAK
Wisata daerah pesisir merupakan salah satu bentuk penerapan pembangunan pariwisata berbasis masyarakat dan berkelanjutan. Melalui pengembangan Gampong wisata diharapkan terjadi pemerataan yang sesuai dengan konsep pembangunan pariwisata yang berkesinambungan.Keikutsertaan masyarakat merupakan hal yang penting dalam pelaksanaan pembangunan.Pada kenyataannya sering terjadi pengabaian partisipasi masyarakat, sehingga masyarakat masih menjadi objek dari pelaksanaan pengelolaan.Pengembangan gampong wisata merupakan sebuah perubahan terencana yang di dalamnya membutuhkan partisipasi masyarakat lokal secara holistik.Kegiatan ini bertujuan: Memberikan gambaran bagaimana pengembangan dan pengelolaan objek wisata yang berbasis masyarakat local. Pengembangan Gampong Suak Indrapuri Kabupaten Aceh Barat, Provinsi Aceh menjadi Gampong wisata belum sepenuhnya melibatkan partisipasi masyarakat. Tantangan dalam proses pengembangan gampong wisata di Suak Indrapuri adalah kurangnya kerjasama antara pemerintah daerah/ Dinas terkait dan perangkat gampong dalam keseluruhan proses pengembangan wisata. Padahal bila mengacu pada pendekatan tata kelola pemerintah yang bersih dan berkelanjutan peran pemerintah diharapkan menjadi fasilitator dengan memberikan peran dan manfaat yang lebih besar kepada masyarakat lokal.Koordinasi yang baik mampu mengembangkan kawasan tersebut. Sangat diharapkan sumberdaya alam yang ada berkelanjutan tanpa mengurangi dan merusak kualitasnya.
\end{abstract}

Kata kunci : Pengembangan, Pengelolaan, Wisata.

\begin{abstract}
Tourism coastal area is one form of application of community-based and sustainable tourism development. Through the development of tourist villages are expected to occur equitable in accordance with the concept of sustainable tourism development. Community participation is important in the implementation of development. In reality there is often a neglect of community participation, so that the community is still the object of the implementation of management. The development of the tourism village is a planned change in which local participation is required holistically. This activity aims: Provides an overview of how the development and management of attractions based on local communities. The development of Suak Indrapuri Village, Aceh Barat Regency, Aceh Province into a tourist village has not fully involved community participation. The challenge in the process of developing the tourist gampong in Suak Indrapuri is the lack of cooperation between local government / related agencies and gampong devices in the whole process of tourism development. Whereas when referring to a clean and sustainable government governance approach the role of the government is expected to be a facilitator by providing greater role and benefits to the local community. Good coordination is able to develop the area. It is desirable that existing natural resources are sustainable without reducing and damaging their quality.
\end{abstract}

Keywords : Development, management, tourism

\section{PENDAHULUAN}

Pariwisata merupakan sektor andalan dalam menunjang pembangunan nasional dan pariwisata mempunyai peran yang sangat penting dalam pertumbuhan perekonomian nasional karena pariwisata dapat menghasilkan devisa, menciptakan 
lapangan kerja dan kesempatan berusaha. Sebagai negara kepulauan terbesar didunia yang memiliki 17.508 buah pulau baik pulau besar maupun pulau-pulau kecil dengan panjang garis pantai $81.000 \mathrm{~km}$ dan luas laut 5,8 juta $\mathrm{km}^{2}$ atau 70 persen luas total Indonesia (Alikodra, 2012) dimana didalamnya terkandung potensi sumberdaya alam yang sangat luar biasa baik flora maupun fauna yang merupakan daya tarik bagi pengembangan pariwisata nasional.

Wilayah laut, pesisir, dan pulau-pulau kecil punya daya tarik bagi pengembangan wisata.Dalam memanfaatkan sumberdaya tersebut sebagai kegiatan pariwisata, sangat penting untuk menjaga kelestarian dan keberlanjutan sumberdaya agar dampak yang ditimbulkan terhadap aktivitas wisata tidak merusak ekosistem dan lingkungannya termasuk sumberdaya didalamnya.Maka wisata yang mesti dikembangkan adalah wisata yang ramah lingkungan dan berkelanjutan seperti ekowisata.

Pengelolaan berbasis masyarakat atau biasa disebut Community-Based Management (CBM) menurut Zamani dan Darmawan (2000) merupakan salah satu pendekatan pengelolaan sumber daya alam, misalnya perikanan, yang meletakkan pengetahuan dan kesadaran lingkungan masyarakat lokal sebagai dasar pengelolaannya. Selain itu, mereka juga memiliki akar budaya yang kuat dan biasanya tergabung dalam kepercayaannya (religion).

Pengembangan berbasis masyarakat (community based tourism-CBT) merupakan model pembangunan yang memberikan peluang yang sebesar-besarnya kepada masyarakat pedesaan untuk berpartisipasi dalam pembangunan pariwisata.CBT merupakan sebuah kegiatan pembangunan pariwisata yang dilakukan sepenuhnya oleh masyarakat.Ide kegiatan dan pengelolaan dilakukan seluruhnya oleh masyarakat secara partisipatif, dan manfaatnya dirasakan langsung oleh masyarakat lokal. Dengan demikian, dalam CBT peran masyarakat local sebagai pemangku kepentingan merupakan unsur terpenting dalam pengembangan Gampong wisata. Gampong wisata merupakan salah satu bentuk penerapan pembangunan pariwisata berbasis masyarakat dan berkelanjutan.Melalui pengembangan Gampong wisata diharapkan terjadi pemerataan yang sesuai dengan konsep pembangunan pariwisata yang berkesinambungan. Di samping itu, keberadaan Gampong wisata menjadikan produk wisata lebih bernilai budaya pedesaan sehingga pengembangan Gampong wisata bernilai budaya tanpa merusaknya. Inskeep (1991) mengatakan bahwa Desa Wisata merupakan bentuk pariwisata yang sekelompok kecil wisatawan tinggal di dalam atau di dekat kehidupan tradisional atau di desa-desa terpencil dan mempelajari kehidupan desa dan lingkungan setempat.

Zamani dan Darmawan (2000) memberikan definisi sebagai : "A strategy for achieving a people-centered development where the focus of decision making with regard to the sustainable use of natural resources in an area lies with the people in the communities of that area" atau "Suatu strategi untuk mencapai pembangunan yang berpusat pada manusia, dimana pusat pengambilan keputusan mengenai pemanfaatan sumber daya secara berkelanjutan di suatu daerah berada ditangan organisasi-organisasi dalam masyarakat di daerah tersebut". Selanjutnya dikatakan bahwa dalam sistem pengelolaan ini, masyarakat diberikan kesempatan dan tanggung jawab dalam melakukan pengelolaan terhadap sumber daya yang dimilikinya, dimana masyarakat sendiri yang mendefinisikan kebutuhan, tujuan dan aspirasinya serta 
masyarakat itu pula yang membuat keputusan demi kesejahteraannya. Dengan demikian pengelolaan wilayah pesisir berbasis masyarakat adalah pendekatan pengelolaan yang melibatkan kerja sama antara masyarakat setempat dan pemerintah dalam bentuk pengelolaan secara bersama dimana masyarakat berpartisipasi aktif baik dalam perencanaan sampai pada pelaksanaannya.

Pemanfaatan secara optimal dan lestari adalah salah satu yang menjadi pertimbangan utama di dalam pengelolaan sumber daya. Pemanfaatan secara lestari hanya akan dicapai jika sumber daya dikelola secara baik, proporsional dan transparan. Sumber daya yang dimaksud adalah sumber daya manusia, alam, buatan dan sosial (Keraf, 2000). Pengembangan dan pengelolaan daerah pesisir di Indonesia bukan hanya tanggung jawab dari pemerintah pusat tetapi kewenangan tersebut telah dilimpahkan kepada pemerintah daerah dengan dikeluarkannya UU No. 22 tahun 1999 yang memberikan kewenangan pada daerah dalam mengelola pesisir dan lautnya sejauh 12 mil untuk propinsi dan 1/3 untuk kabupaten (UU No. 22 tahun 1999).

\section{Permasalahan}

Mempertimbangkan karakteristik masyarakat pesisir sebagai komponen yang paling banyak menggunakan sumber daya diantaranya mengelola kawasan wisata.Pengelolaan kawasan wisata hendaknya (1) berbasis lokal; (2) berorientasi pada peningkatan kesejahteraan; (3) berbasis kemitraan; dan (5) berkelanjutan.Pengelolaan berbasis lokal adalah pengelolaan itu bukan saja dilakukan oleh pihak pemerintah setempat tetapi juga melibatkan sumber daya lokal sehingga akhirnya return to local resource dapat dinikmati oleh masyarakat lokal.

\section{Tujuan Kegiatan}

Adapun tujuan dari kegiatan pengabdian kepada masyarakat ini adalah sebagai berikut:

1. Memberikan gambaran bagaimana pengembangan dan pengelolaan objek wisata

2. Pengelolaan yang berbasis masyarakat local 


\section{METODELOGI}

\section{Tempat dan Waktu}

Pelaksanaan kegiatan ini telah dilaksanakan pada tanggal 04 November 2016.Berlangsung di Balai Gampong Suak Indrapuri Kecamatan Johan Pahlawan (Gambar 1).

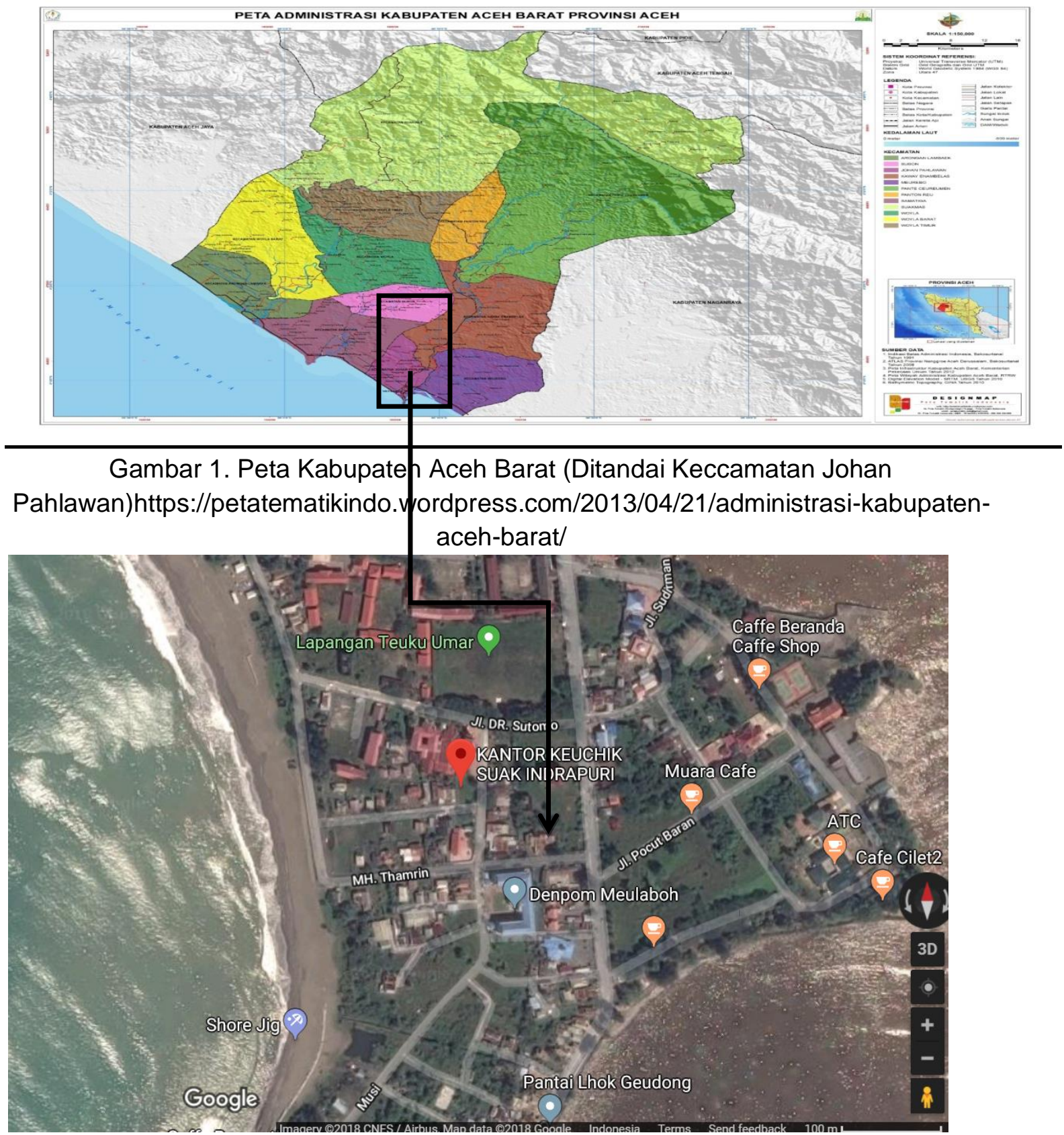

Gambar 2. Gampong Suak Indrapuri

\section{Teknik Pelaksanaan}

Pendekatan yang dilakukan adalah dengan memberikan wawasan dan juga memberikan informasi tentang bagaimana mengembangkan dan mengelola objek wisata yang berbasis masyarakat.Bentuk kegiatan yang dilakukan adalah dengan memberikan ceramah dan Tanya jawab/diskusi (Gambar 3 dan 4). 


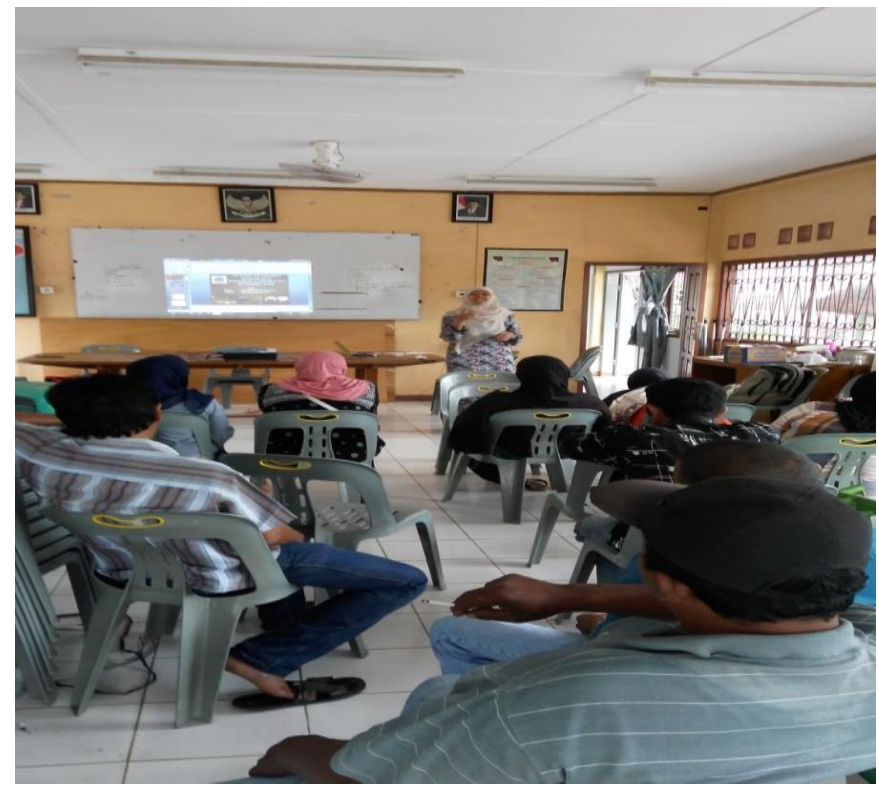

Gambar 3. Memberikan Paparan

\section{HASIL DAN PEMBAHASAN}

Pada awal kegiatan saya memberi paparan tentang kawasan wisata yang berbasis masyarakat. Melibatkan masyarakat dalam pengembangan adalah hal yang penting diletakkan atas dasar keyakinan bahwa masyarakatlah yang paling tahu apa yang dibutuhkan di kawasan tersebut. Partisipasi yang hakiki akan melibatkan masyarakat dalam keseluruhan tahapan pengembangan, mulai dari proses perencanaan, pengambilan keputusan, dan pengawasan program pengembangan Gampong wisata. Keikutsertaan masyarakat ini sangat dipengaruhi oleh kemauan, kesempatan, dan kemampuan dari masyarakat tersebut Keikutsertaan masyarakat dalam perencanaan Gampong wisata dapat mendorong mereka berpartisipasi aktif dalam pelaksanaan dan pengawasan. Berdasarkan hal tersebut dapat dirumuskan model pengembangan pariwisata berbasis masyarakat. Parameter yang digunakan untuk menentukan derajat partisipasi masyarakat dalam tahap perencanaan adalah keterlibatan dalam identifikasi masalah, perumusan tujuan, dan pengambilan keputusan terkait pengembangan Gampong wisata. Sebagian besar masyarakat Suak Indrapuri mengaku tidak dilibatkan dalam identifikasi masalah dan tidak ikut terlibat dalam pengambilan keputusan terkait pengembangan Gampong wisata. Mereka tidak pernah diajak berdialog dalam mengidentifikasi kebutuhan masyarakat lokal. Hal ini terjadi, karena:

(1) Gagasan pengembangan Gampong wisata dilakukan oleh Pemerintah Kabupaten Kuningan tanpa melibatkan masyarakat sebagai pemilik sumber daya, sehingga masyarakat Suak Indrapuri kurang memahami latar belakang pengembangan Gampong wisata;

(2) Masyarakat lokal hanya menjalankan apa yang diprogamkan oleh pemerintah, misalnya, kesediaan menerima kedatangan wisatawan dan menyerahkan lahan untuk dibangun fasilitas wisata; dan

(3) Masyarakat lokal tidak berkekuatan untuk berpartisipasi aktif dalam arti ikut memberi warna terhadap keputusan yang akan diambil oleh penguasa. 
Meskipun masyarakat diundang dalam beberapa rapat perencanaan, partisipasi yang dilakukan oleh masyarakat pada tahap ini tergolong semu. Benefit yang diperoleh dari bentuk partisipasi yang dilakukan tidak menunjukkan hasil yang signifikan, bahkan umpan balik yang disampaikan oleh masyarakat lokal atas keputusan yang diambil oleh penguasa sering diabaikan. Padahal substansi dalam pengembangan Gampong wisata berbasis masyarakat, partisipasi yang dilakukan oleh masyarakat Suak Indrapuri seharusnya bersifat aktif dan langsung. Namun, selalu dihadang oleh keputusan penguasa yang bersifat topdown.

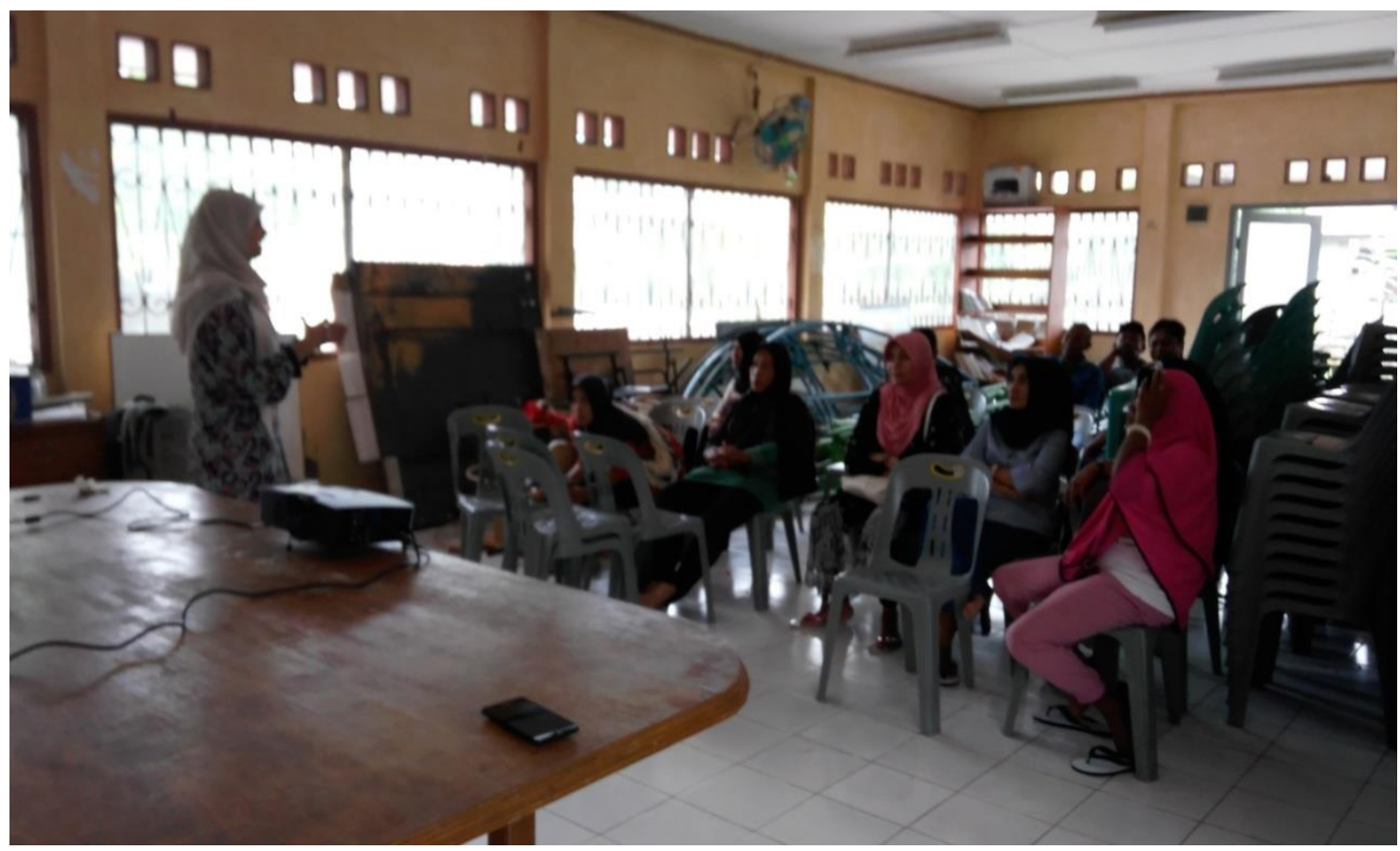

Gambar 4. Diskusi

Mekanisme seperti ini menjadikan masyarakat Suak Indrapuri tidak terbiasa berpartisipasi.Ketergantungan terhadap pemerintah dan investor tinggi.Kondisi ini berakibat pada kurangnya respons, antusiasme, dan keterlibatan masyarakat dalam pengelolaan dan pengembangan aset-aset di wilayah mereka. Dalam hal keaktifan masyarakat Gampong Suak Indrapuri, hasil penelitian menemukan bahwa kehadiran warga dalam pertemuan Gampong cukup antusias. Walaupun warga masyarakat banyak yang hadir dalam setiap pertemuan, pada umumnya mereka mengaku tidak terlibat dalam pengambilan keputusan perihal pengembangan Gampong wisata.Berdasarkan hal tersebut difahami bahwa kesempatan untuk berpartisipasi bagi masyarakat belum terbuka lebar.Masyarakat memiliki kemauan yang besar untuk turut berkontribusi dalam pembangunan wilayahnya, namun kesempatan untuk mengemukakan pendapat dan mengambil keputusan tidak tersedia.Hal ini disebabkan pemerintah telah memiliki rencana pembangunan yang telah dicanangkan sejak tahuntahun sebelumnya, sehingga masyarakat hanya sebagai objek dari perubahan yang ada.Isu menarik lainnya adalah keterwakilan masyarakat. Meskipun peserta yang hadir dalam perencanaan pengembangan Gampong wisata berasal dari berbagai latar belakang, hal ini belum mencerminkan keterwakilan. Pertemuan-pertemuan itu 
biasanya dihadiri oleh tokoh masyarakat, pejabat Gampong, kelompok tertentu, warga masyarakat yang berpendidikan, misalnya guru, pegawai negeri sipil, dan ulama, yang secara resmi diundang oleh kepala Gampong. Kondisi ini mengindikasikan bahwa pengembangan Gampong wisata belum sepenuhnya melibatkan seluruh lapisan masyarakat hingga level grassroot karena dominasinya adalah golongan menengah ke atas, termasuk para pelajar, orang berpendidikan, dan para pemimpin informal. Sehingga masyarakat yang benar-benar ada di level bawah tidak terdengar aspirasinya.

Partisipasi masyarakat dalam pengembangan Gampong wisata pada prinsipnya adalah partisipasi dalam mengelola sumber daya. Oleh karena itu, perlu dirumuskan model yang relevan dalam pelaksanaan program tersebut.Model dipandang sebagai acuan dalam merencanakan, mengimplementasi, dan mengevaluasi program.Sebagai sebuah pendekatan, model yang dirumuskan harus merepresentasikan partisipasi masyarakat dalam setiap aspeknya. Harapan masyarakat Suak Indrapuri dalam pengembangan Gampong wisata kedepan adalah:

1. Pengembangan Gampong wisata harus berpedoman pada potensi masyarakat dan lingkungan;

2. Masyarakat harus terlibat penuh dalam pengembangan Gampong wisata;

3. Menghargai hak-hak masyarakat local;

4. Memperhatikan kelestarian lingkungan yang ada di sekitar Gampong Suak Indrapuri; dan

5. Ada kelembagaan otonom dan mandiri yang dibentuk oleh masyarakat lokal dibawah tanggung jawab Gampong adat. Ada jaminan bahwa masyarakat harus terlibat di dalamnya agar program pengembangan Gampong wisata berjalan sesuai dengan kebutuhan masyarakat.

Siddiq \& Risna (2016) mengemukakan untuk menjamin hal itu dirumuskan halhal sebagai berikut:

1. Pengembangan Gampong wisata harus berpedomanan pada kebudayaan local masyarakat;

2. Masyarakat lokal menjadi sentral dan menjadikan subjek dari semua proses pengembangan Gampong wisata. Dengan menempatkan masyarakat sebagai sentral diharapkan partisipasi masyarakat sebagai pemilik sumber daya pariwisata akan terdorong dan mampu menyejahterakan masyarakat local;

3. Pengembangan Gampong wisata membutuhkan adanya kemitraan yang solid antara tiga unsur utama, yaitu pemerintah, swasta, dan lembaga, yang masyarakat lokal menjadi pemangku kepentingan dari kerja sama tersebut;

4. Ketiga pemangku kepentingan tersebut berada pada posisi yang sejajar dalam melakukan kerja sama serta saling menghormati;

5. Perlu dibentuk badan pengelola yang otonom dan mandiri, yang saling berinteraksi, memberikan umpan balik pelaksanaan untuk mengoreksi diri pada setiap jenjang organisasi;

6. Keputusan dan inisiatif untuk memenuhi kebutuhan masyarakat lokal dibuat ditingkat lokal oleh warga masyarakat yang memiliki identitas yang diakui peranannya sebagai partisipan dalam proses pengambilan keputusan; dan 
7. Fokus utama pengembangan Gampong wisata adalah memperkuat kemampuan masyarakat lokal dalam mengarahkan dan mengatasi aset-aset yang ada pada masyarakat local untuk memenuhi kebutuhannya.

Pelaksanaan hubungan antar pemangku kepentingan tersebut terarah, peran dan tanggung jawab masing-masing harus jelas.Peran dan kewenangan masingmasing pemangku kepentingan sebagai berikut. Peran dan Kewenangan Pemerintah, yaitu

1. Melakukan pembinaan kualitas produk dan kemasan kerajinan dan kuliner khas Gampong sebagai unsur kenangan wisata;

2. Melakukan penataan dan konservasi lingkungan fisik kawasan yang menjadi ciri khas Gampong wisata;

3. Melakukan perbaikan/pengadaan infrastruktur persampahan dan sanitasi;

4. Melakukan gerakan masyarakat untuk mewujudkan sapta pesona; M

5. Melakukan pembuatan informasi dan fasilitas kepariwisataan;

6. Melakukan perbaikan/peningkatan kualitas ruang publik, pedestrian dan landscape Gampong/lingkungan untuk mendukung sapta pesona; dan

7. Dukungan pemberdayaan terhadap kelompok sadar wisata (Pokdarwis) dalam pelestarian lingkungan pariwisata.

Peran dan Kewenangan Swasta (Investor, Perguruan Tinggi, LSM, pelaku pariwisata lainnya), yaitu

1. Melakukan promosi terintegrasi antar pengelola objek wisata untuk menggerakkan kunjungan wisatawan antar objek wisata;

2. Pembuatan dan pemasaran paket-paket wisata yang kompetitif yang terjangkau masyarakat;

3. Pelatihan kewirausahaan, pelatihan keterampilan individual terkait usaha di bidang pariwisata (pelatihan bahasa Inggris, pelatihan hospitality, pelatihan mengenal budaya, dan karakteristik wisatawan dalam dan luar negeri);

4. Pengembangan kelompok usaha bersama masyarakat; dan

5. Menjalankan bisnis perhotelan, restoran, suvenir, dan lainlain.

Peran masyarakat Lokal, yaitu

1. Menyediakan sebagian besar atraksi sekaligus menentukan kualitas produk wisata. Pengelolaan lahan pertanian secara tradisional, upacara adat, kerajinan tangan dan kebersihan merupakan beberapa contoh peran yang memberikan daya tarik bagi pariwisata;

2. Pelaku budaya, misalnya, kesenian yang menjadi salah satu daya tarik wisata; dan

3. Penyedia akomodasi dan jasa pemandu wisata, penyediaan tenaga kerja, produk makanan khas, kerajinan lokal, kesenian lokal, dan sebagainya.

Peran dan Kewenangan Badan Pengelola, yaitu

1. Badan pengelola sebagai pengelola utama dan pengarah dalam perlindungan, perawatan, pelestarian guna mempertahankan fungsinya sebagai Gampong wisata (cultural and natural heritage); 
2. Melakukan pengaturan yang diperlukan dalam rangka pengembangan Gampong Wisata Suak Indrapuri;

3. Menyediakan dan mengoperasikan segala fasilitas untuk menunjang kegiatan usaha;

4. Memberikan dan mecabut izin penempatan, menetapkan persyaratanpersyaratan, dan menetapkan serta melakukan pungutan segala usaha komersial di Gampong Wisata Suak Indrapuri;

5. Menetapkan dan memungut biaya/retribusi dan pungutan lainnya atas pemanfaatan fasilitas yang tersedia dan hasil seluruhnya merupakan pendapatan badan pengelola;

6. Melakukan perencanaan dalam bidang pengembangan atraksi/produk wisata, pengembangan fasilitas wisata;

7. Melakukan pengorganisasian dalam bidang penguatan dan pengembangan kelembagaan;

8. Melakukan pengarahan untuk peningkatan kompetensi pengelola objek wisata agar sesuai dengan tujuan pengembangan Gampong wisata yang berkelanjutan; dan

9. Melakukan evaluasi dan pengawasan terhadap aktivitas kepariwisataan agar tercapainya tujuan pengembangan Gampong wisata yang berkelanjutan.

\section{PENUTUP \\ Kesimpulan}

Peran pemerintah dalam pengelolaan sumber daya pariwisata terlihat dominan.Padahal bila mengacu pada pendekatan tata kelola pemerintah yang bersih dan berkelanjutan peran pemerintah diharapkan menjadi fasilitator dengan memberikan peran dan manfaat yang lebih besar kepada masyarakat.Hal ini menunjukkan bahwa pembangunan pariwisata berbasis partisipasi masyarakat belum terwujud di wilayah ini.Masyarakat belum menjadi subjek utama pembangunan, namun masih menjadi objek pembangunan.Hal ini disebabkan kesempatan untuk berpartisipasi masih terbatas.Keran untuk berpartisipasi masih belum terbuka lebar.Masyarakat merasa tergusur oleh perubahan yang terjadi tanpa memiliki kemampuan untuk turut terlibat dalam pembangunan. Masyarakat lokal khususnya masyarakat Suak Indrapuri perlu diajak untuk mendesain sendiri model pariwisata yang akan dikembangkan. Selama ini pariwisata yang dikembangkan di Gampong wisata tersebut tidak pernah di desain oleh mereka. Pariwisata yang dikembangkan didesain oleh orang luar Gampong. Masyarakat lokal terpinggirkan. Pengembangan Gampong wisata berjalan sesuai dengan kebutuhan masyarakat, harus ada jaminan masyarakat untuk terlibat di dalamnya. Untuk menjamin hal itu diperlukan kemauan politik pemerintah untuk mengurangi peranannya dalam pengembangan Gampong wisata dan memberikan peranan yang lebih besar kepada masyarakat dengan membuka ruang bagi masyarakat untuk berpartisipasi. Selama ini masyarakat terbiasa menjalankan apa yang diperintahkan oleh pemerintah dan tidak dibiasakan berpartisipasi. 


\section{DAFTAR PUSTAKA}

Alikodra, Hadi S. 2012, Konservasi Sumber Daya Alam dan Lingkungan. Pendekatan Ecosophy bagi Penyelamatan Bumi, cetakan ke-1, Gadjah. Mada Universityy Press:Yogyakarta.

Siddiq, A. J \& Risna. R.2016 .Pengembangan Desa Wisata Berbasis PartisipasiMasyarakat Lokal Di Desa Wisata Suak IndrapuriKuningan, Jawa Barat. Prosiding KS: Riset \& PKM. Volume 4.Nomor 1. Hal: 1-140. ISSN: 2442-4480.

Zamani, N.P dan Darmawan, 2000. Pengelolaan Sumber daya Pesisir Terpadu Berbasis Masyarakat. Prosiding Pelatihan untuk Pelatih Pengelolaan Wilayah Pesisir Terpadu, Bogor 21 - 26 Februari 2000. Pusat Kajian Sumber daya Pesisir dan Lautan IPB, Bogor. 